\title{
TRADE DEVELOPMENT BETWEEN THE EUROPEAN UNION AND MEMBERS OF THE EASTERN PARTNERSHIP PROGRAMME. EXAMPLE OF UKRAINE AND POLAND
}

\author{
Daniel BUTYTER \\ University of Wroclaw \\ doi:10.13165/IE-14-8-1-05
}

\begin{abstract}
Eastern dimension of the European Union is one of the most important dimensions of the European Neighbourhood Policy. Eastern Partnership is a programme aimed at tightening cooperation between the EU and its partners. The result of the Eastern Partnership programme should be the signature of DCFTA with each partner. Signing of such a Treaty can bring advantages and disadvantages as well as dangers for both sides. This article studies the best option for the economic integration for Eastern Partnership countries customs union of Russia, Belarus and Kazakhstan or the free trade zone with the European Union. Ukraine and Poland have close historical, economical, cultural and economic ties. Their example is the best for the analysis of economic and trans-border cooperation between the EU and Eastern Partnership countries.
\end{abstract}

JEL classification: F10, F13, F15, F51.

Keywords: Eastern Partnership, border, European Union, Ukraine, trade creation, trade diversion effect, international trade, free trade agreement, customs union.

Reikšminiai žodžiai: Rytų partnerystė, ES, Ukraina, tarptautinė prekyba, prekybos diversifikacijos efektas, laisvos prekybos sutartis, Muitų sąunga.

\section{Introduction}

The European Union is the first or the second (after Russia) trade partner of each Eastern Partnership country and plays huge role in their foreign trade. Trade policy of every Eastern Partnership member should be based on integration with the European Union or integration with Russia.

The main goal of the article is to show the positive sides of elimination of borders between the EU and Eastern Partnership members and increase trade between them, which would be determined by the enlargement of the customs union and other positive economic effects. The purpose of this study is to formulate the problems of the EU borders and analyse changes in their character. The author believes that the objectives of the study reveal the essence of the border and are to characterise its components and highlight the conceptual framework of the Eastern border of the EU. From all Eastern 
European members, Ukraine is the closest to create a free trade area with the European Union. That is why it has been chosen for research. The hypothesis of the study is that the transformation of the EU border should be considered as a dynamic model of fundamental transformational changes, not only in a geographical sense, but also in the wider socio-economic, geopolitical dimensions.

\section{Characteristics of the Eastern Partnership Programme}

Eastern Partnership is a programme of the European Union aimed at strengthening the economic and political relations of the EU with its Eastern Neighbours. This programme is actually the continuation of the eastern direction of the existing European Neighbourhood Policy.

For the first time the project of Eastern Partnership was introduced by Sweden and Poland in May 2008 and it was assumed to strengthen cooperation in the main economic, political and social fields.

The project includes from the European Union on one side and Armenia, Azerbaijan, Georgia, Moldavia and Ukraine on the other side. Belarus also used to belong to it, but on 30 September 2011 the country resigned from membership in the Eastern Partnership due to many political (non-democratic regime of the President Lukashenka) and economic (creating of the customs union with Russia and Kazakhstan) issues.

The present government of Moldavia believes in the highest necessity of joining the EU for the future development of the country. "I cannot see any other solution for Moldavia but its membership in the European Union" - announced the Minister of Foreign Affairs of Moldavia Iurie Leancă. The main priorities of the country include EU visa exemption, free trade zone, common airspace, and common energy cooperation.

Among the three countries of the Northern Caucasus, Georgia is the one the most interested in the development of relations with the European Union. Azerbaijan and Armenia do not show the slightest interest in the EU membership.

Azerbaijan is mostly interested in energy cooperation within the Eastern Partnership. Actually, it does not matter whether it will happen within the Eastern Partnership or on the basis of some other multi-sided agreements - the form of cooperation does not play any significant role in this case. Visa exemption seems to be an issue of special concern for the government.

Armenia seems to be interested in the Eastern Partnership only in terms of cooperation that leads to financial benefits. That is the reason for the great interest of the country in the free trade zone with the European Union.

As for Georgia, the cooperation is quite complex. Georgia has not signed many agreements with the EU and these agreements are concern integration: again simplification of the visa process for Georgian citizens. In July 2010 the work was started on creating common associations, and in October 2010 an agreement was signed declaring the will of creating complex programmes of institutional development. All of this shows a clear aspiration of Georgia to join the European Union and its European integration.

The Eastern Partnership does not actually include new approaches to economic cooperation with Ukraine. EU and Ukraine are presently negotiating the agreement on 
the association as well as the agreement of the free trade zone. It will take from 10 to 15 years (it depends on the particular economic sector) and will require many efforts from the Ukrainian side in terms of financial and human resources. Undoubtedly, Ukraine is the leader among the Eastern Partnership countries and, therefore, its experience will be very useful for further development of cooperation between the other countries.

Figure 1. European Union and the members of Eastern Partnership

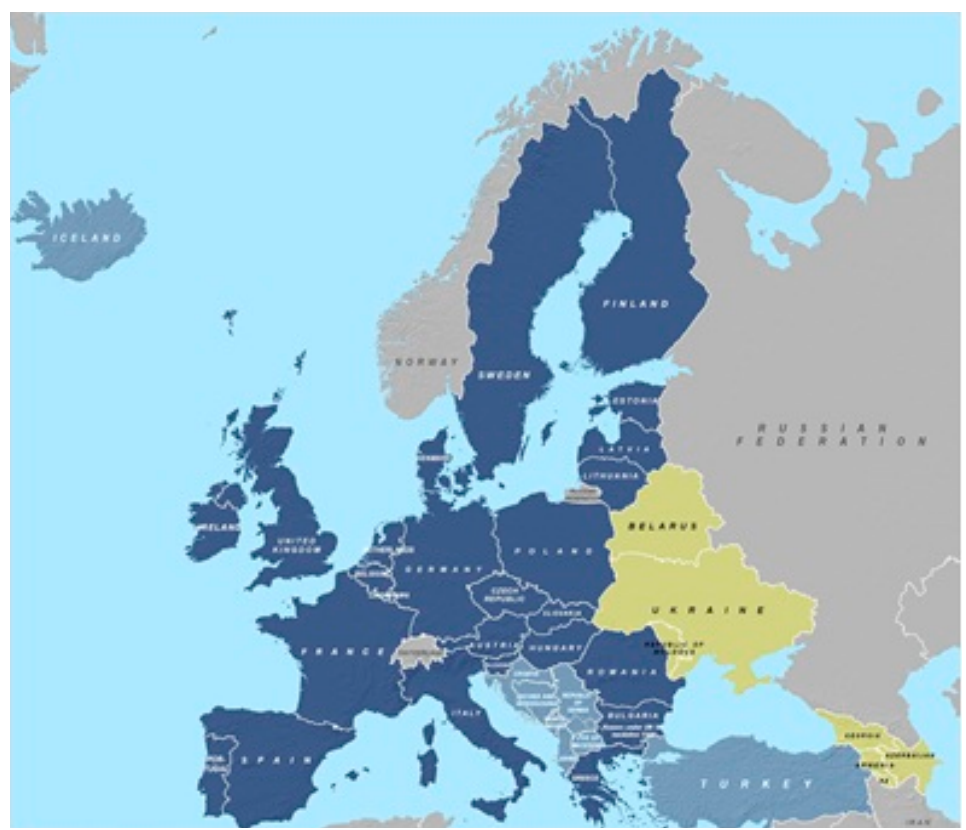

(blue - European Union Member States, yellow - Eastern Partnership countries, light-blue -candidate countries for the $\mathrm{EU}$ accession, grey - other countries)

Introducing the Eastern Partnership policy exerted positive influence and beneficial effect on both sides. Despite the fact that European integration has not been the main purpose of the programme, its results nevertheless have a clear cultural and political character. The overall effect was the mutual interest of the European countries and their Eastern neighbours.

Eastern Partnership is not a promise of EU membership for its participants, but for those who are interested in it in the future it might be a very meaningful experience which is difficult to overestimate.

During the next Eastern Partnership summit, which will be held in Vilnius on 2829 November 2013, a Deep and Comprehensive Free Trade agreement will supposedly be signed with 3 Eastern Partnership members - Ukraine, Moldavia, Georgia. Ukraine has the highest chance of signing DCFTA. 


\section{Free trade agreements with Eastern Partnership members}

All members of the Eastern Partnership are preparing to sign an Association Agreement with the European Union in the nearest future, which will include an agreement on deep and comprehensive Free Trade Area (DCFTA).

The deep and comprehensive approach to trade is a very sensitive and quite complex subject. This approach goes much further than a simple free trade agreement (that merely aims to eliminate/abolish import tariffs and quotas), but contemplates an agreement covering the whole framework of trade and trade-related legislation, as well as setting forth standards compatible with those of the European Union. A DCFTA involves far-reaching elimination of barriers to trade and investment throughout various sectors of the economy. In addition to removing more tariff barriers to trade, a DCFTA will also provide a platform for addressing non-tariff barriers by both parties according to the same rules of game.

A DCFTA covers integration along all trade-related areas, and also tackles the socalled "beyond the border" obstacles to trade through deep regulatory approximation with the trade-related EU acquis. This exercise will lead to institutional reforms and transparent regulations which will give impulse to the economy and favour sustainable growth, as well as the modernization of countries. However, these reforms have to be supported by a diversification of trade and particularly by the increase of exports.

Still members of Eastern Partnership face different problems.

Ukraine has made the greatest progress among Eastern Partnership states in the process of European integration. The country's political elite unanimously agrees that it is necessary to deepen co-operation with the European Union.

In 1994, Ukraine signed the Partnership and Co-operation Agreement with the EU, which came into force in 1998. Ukraine was covered by the European Neighbourhood Policy from the outset, and adopted the ENP Action Plan in 2005. Negotiations of the Association Agreement, which will include an agreement on a Deep and Comprehensive Free Trade Area (DCFTA), were launched in 2007. The signature and the implementation of the agreement will have a major impact on the relations between Ukraine and the EU and should contribute to the modernisation of Ukraine through the adoption of the EU standards. The agreement with Ukraine is expected to be a model for association agreements with other EaP states. At the moment, however, the negotiations are in a stalemate, as authorities in Kiev are not willing to accept all the EU conditions related to DCFTA, which they regard as harmful for Ukrainian economy. It is unlikely that negotiations will be successfully concluded by the second half of 2011 .

Visa facilitation and readmission agreements entered into force in 2008. The same year a 'visa dialogue' was launched. During the EU-Ukraine summit in Brussels on 22 November Kiev was given an Action Plan for visa liberalisation, a document that sets out technical conditions necessary for visa waiver.

During 2012, export quantity from Ukraine to the EU countries diminished in comparison to the previous year - it reached the value of $\$ 14.5$ bln ( $\$ 15.0$ bln in 2011), but import quantity increased from \$21.2 bln in 2011 to $\$ 23.7$ bln in 2012 . 
Signing DCFTA between Ukraine and the EU will result in increasing the export of goods from Ukraine to the Western European market, which is a key factor and consequently will lead to increased GDP.

According to declarations, European integration is a priority issue in the foreign policy of Moldova. After the elections in 2011 the new government consists of genuine supporters of the strongest possible rapprochement of Moldova and the EU. At present, Moldova is the second most advanced country (after Ukraine) in dialogue with the EU.

Moldova signed a Partnership and Co-operation Agreement with the EU in 1994. Starting in 2003, the European Union became one of the key trade partners of Moldova. Achieving greater access of our goods and services to the European market is now a challenge for all involved stakeholders. In 2003, it was covered by the European Neighbourhood Policy, and it adopted the Action Plan in 2005. The agreement on the liberalisation of the visa regime came into force in 2008. In June 2010, Chisinau and Brussels started a visa dialogue aimed at achieving a road towards lifting the visa requirement, and in January 2011 the EU granted Moldova a visa facilitation action plan.

Research shows that signing the DCFTA will have an immense positive impact on the economic growth of Moldova. Moldova needs a trade agreement of a new generation. A DCFTA for Moldova can become the main vehicle for having real free trade with the EU, but to achieve this, Moldavia's economy has to undergo far reaching regulatory reforms. In 2010, negotiations were launched on the new Association Agreement that will include deep and comprehensive free trade area. The new agreement is set to replace the old PCA.

Export quantity from Moldova to the EU countries expanded during 2012 in comparison to the previous year - it reached the value of $\$ 0.9$ bln ( $\$ 0.8$ bln in 2011), import quantity also increased from \$ 1.9 bln in 2011 to \$ 2.0 bln in 2012 .

Among the three Caucasian states, Georgia is the most interested in deepening its relations with the EU. In 2006, the EU and Georgia adopted the Five-Year Action Plan of the European Neighbourhood Policy. In May 2009 Georgia joined the Eastern Partnership initiative. Negotiations on readmission and visa facilitation have been closed, and are expected to come into force in early 2011. In late 2009, the EU and Georgia established a Mobility Partnership. Negotiations on the Association Agreement started in July 2010. The new agreement will set up a deep and comprehensive free trade area (DCFTA) between Georgia and the EU. In October 2010, Georgia and the EU signed a $\mathrm{MoU}$ on Comprehensive Institution Building programmes, aiming at strengthening the capacity of Georgia's public administration. To this end, the EU has allocated $€ 31 \mathrm{~m}$.

During the 2008 Georgian-Russian war, the EU served as a mediator in negotiating the peace agreement between Moscow and Tbilisi. After the war, the EU sent a monitoring mission (EUMM) to monitor regions of conflicts (though Abkhazia and South Ossetia have denied access of the EUMM to their territories). In addition, the EU allocated an extra $€ 500$ million for post-war reconstruction, thereby substantially increasing the original sum of $€ 120$ million earmarked for Georgia as part of the ENPI financial instrument for the years 2007-2010, and $€ 180$ million for the years 2011-2013.

The framework for co-operation between the EU and Azerbaijan has been defined in the Partnership and Co-operation Agreement (PCA) signed in 1996 and in force 
since 1999. Azerbaijan is covered by the European Neighbourhood Policy (the relevant Action Plan was adopted in 2006) and the Eastern Partnership initiative. In its relations with the EU, Azerbaijan is mainly focused on increasing its presence on the EU's energy market. Negotiations on the association agreement started in July 2010, although the document will not include the deep and comprehensive free trade area (DCFTA), as Azerbaijan does not meet the basic requirement defined by the EU, namely membership in the WTO. Brussels and Baku are involved in a technical dialogue on visa liberalisation and the conclusion of a readmission agreement, though the relevant negotiations have not started yet. The EU has earmarked $€ 92$ million of assistance for Azerbaijan as part of the ENPI financial instrument in the years 2007-2010, and €122.5 million in 2011-2013. In January 2011 the EU and Azerbaijan signed a MoU on Comprehensive Institution Building - a programme aimed at improving capabilities of Azerbaijani public institutions, so that they are more compatible with the EU institutions. The EU has earmarked $€ 19 \mathrm{~m}$ to this end.

The framework for co-operation between the EU and Armenia has been defined in the Partnership and Co-operation Agreement (PCA) signed in 1996 and in force since 1999. In 2006, the EU and Armenia adopted the 5-year Action Plan of the European Neighbourhood Policy. In May 2009, Armenia joined the Eastern Partnership initiative. Negotiations concerning the new Association Agreement, which will replace the PCA, were launched in 2010. The new agreement will include provisions on the creation of a deep and comprehensive free trade area (DCFTA). Brussels and Yerevan are involved in a technical dialogue on visa facilitation and readmission agreement, though the negotiations have not started yet. In April 2009 the EU sent an advisory group of EU experts to Armenia. The group provides Armenian government with policy advice on issues ranging from human rights and public administration reform to trade-related issues. In November 2010 the EU and Armenia signed a memorandum of understanding on the Comprehensive Institution Building programmes, which should help reform Armenia's public institutions, so that they are capable of aligning the country with the EU standards. To this end, the EU has allocated $€ 31$ million. The EU has earmarked $€ 98$ million of assistance for Armenia as part of the ENPI financial instrument in the years 2007-2010, and €157 million in 2011-2013. The EU supports Armenia's dialogue with Turkey concerning the expected opening of the border between the two countries.

The export quantity from South Caucasus to the EU countries expanded during 2012 in comparison to the previous year -- it reached the value of \$ 15.7 million (\$10.5 million in 2011), import quantity also increased from $\$ 4.0$ million in 2011 to $\$ 5.0$ million in 2012.

Changes in foreign trade between the $\mathrm{EU}$ and $\mathrm{EaP}$ countries can be counted through the calculation of the trade creation and trade diversion effects. Trade creation effect is an international trade term in which trade flows are redirected due to the formation of a free trade area or a customs union. Trade diversion effect is an international trade term in which trade is diverted from more efficient exporter towards a less efficient one in the free trade area or a customs union. They will show if the creation of a free trade area with $\mathrm{EaP}$ countries has positive or negative effect on their foreign trade. For this we need to use the following formulas: 


$$
\begin{aligned}
& T C=\sum_{t=j}^{i}\left(M_{t}-m C_{t}\right), \\
& T D=\sum_{t=i}^{j}\left(N_{t}-n M_{t}\right),
\end{aligned}
$$

where: $N_{t}$-import from the rest of the world in the $t$ year; $M_{t}$ - total amount of import in the $t$ year; $C_{t}$ - consumption, calculated as gross output minus export, plus import in the $t$ year; $m=\frac{N}{M}$ - calculated for the last year before creation of the customs union, $n=\frac{M}{C}-$ calculated for the last year before the creation of customs union.

This method cannot be used to predict the changes in the trade, as to receive output date the customs union or a free trade area must already be established. Thus, we can only approximately predict the changes in trade due to some indicators, which have a direct impact on trade creation and trade diversion. As all EaP members more or less have two ways of conducting their foreign policy, or the EU integration (by creating a FTA), or integration with the customs union formed by Russia, Kazakhstan and Belarus, ant those two integration associations have the biggest impact on EaP countries' foreign trade, the best way to show trade effects will be to compare FTA with the EU and the customs union with Russia:

1. Trade effects depend on the structure of production. Partner countries can have competitive or complementary production. When production is complementary, the benefits from integration are low. In case of competitive production, the specialisation in the production of goods is more likely, where one of the partners will produce better and cheaper, and the benefits will be great. Some branches (for example, agricultural sector in Ukraine) are competitive as against the EU goods. At the same time, some parts of the EU's machinery and machinery building sector are based on raw materials and steel from Ukraine (example of complementary production). Thus, in case of EaP countries, which are the source of cheap resources, the benefits from this point will not be considerable, because exchange in resource production between the EU and $\mathrm{EaP}$ is much bigger (about $45 \%$ of foreign trade in 2012) than in agricultural production (about $12 \%$ of foreign trade). Russia's customs union is also more an exporter of resources to the EU and not of finished goods, which means that in case of creating a FTA trade diversion and trade creation will cover itself and will not bring too many advantages for neither of the sides in world trade (neither to the EU nor to Russia's customs union, nor to the EaP countries).

2. Trade effects depend on the number of countries taking part in the agreement establishing free trade. From this point, for every member of Eastern Partnership creating a free trade area with the EU is much more efficient than creating a customs union with Russia. Population of the EU amounts to 503 million, while in Russia's customs union it is 170 million, the Gross Domestic Product of the European Union is \$ 16.4 trillion, while in Russia's customs union its $\$ 2.3$ trillion. This proves the better option of joining a larger free trade agreement with the EU than a smaller customs union with Russia.

3. Customs have considerable impact on trade effects before creating a free trade area or a customs union with countries with which integration association is created. 
As most EaP countries (except Georgia) are already in the free trade area, joining Russia's customs union will not bring more benefits. Thus, creating a FTA with the EU is reasonable, but even despite this Russia can hamper free trade in its free trade area due to political issues (like the recent blockade of Ukrainian goods in September 2013 on Ukrainian-Russian border).

At the same time, after creating a customs union, new customs become very important. Lower customs in relation to third countries make trade diversion effect lower, what improves the trade situation of the country. In case of EaP countries, the EU offers creating free trade areas, which will not have direct negative impact on foreign trade with third countries. In case of signing into a customs union with Russia it will create a huge diversion effect, as it was with Belarus in 2010. If EaP countries still sign into a customs union with Russia, they will lose the existing benefits from the "mostfavoured nation clause". This will bring clear disadvantages for EaP countries.

4. The last thing that affects trade effects is trade connections. The more trade connections are inside an integration association, the more trade creation effect can be expected, and on the opposite side, the bigger are trade connections with third countries, the more trade diversion can be expected. The main trade partners of Eastern Partnership countries are European Union and Russia. Due to the existing statistical data, foreign trade with Russia and EU for each country was almost the same (for example, Ukraine's foreign trade turnover with Russia occupied $31 \%$ its total trade, while with EU it was $30.5 \%$ in 2012). The exception is Georgia, which, after war with Russia in 2008, almost stopped its trade with the latter. This fact shows that free trade area with the European Union would be more profitable.

All of those facts show that entering into a free trade agreement with the European Union for each EaP member would be more profitable and more rational from economic point of view. However, there are still many political issues left, which are hard to predict, and this can damage free trade between EaP countries and Russia's customs union.

\section{Poland and Ukraine at the new Eastern border of the EU after accession of the new Member States in 2004}

Enlargement of the European Union and accession of Central and Eastern European countries was an important issue for future economic and trade relations with the countries of post-soviet space. It was a consequence of changes in the trading status of the new Member States of the European Union that came together with obtaining full membership and reaching the level of requirements on EU energy security.

Eastern Partnership states were traditional markets for Polish economy. Thus, Poland's accession to the EU should in no way effect its economic relations with those states. Fresh dynamism of the EU Eastern policy, expressed in particular in the everincreasing share of the European Union's participation in the life of this region, clearly matches the interests of Poland.

Improvements in economic and political spheres of the Eastern Partnership countries is in the interest of the EU, as it enables wider expansion of the European market, 
which in turn will accelerate the political transformation in the region. It should help the Eastern Partnership countries in their quest to reach the level of criteria for membership in international economic organisations, such as the World Trade Organization, International Monetary Fund, etc. Achieving these criteria is a precondition for closer cooperation with the European Union.

Poland is a transit country that has taken an open position on matters relating to oil and natural gas transportation from East to West and South of Europe. Poland is interested in the expansion of oil and gas pipelines from the Caspian Sea through the Caucasus (Turkmenistan-Azerbaijan-Georgia-Ukraine). The construction of the Odessa-Brody-Gdansk pipeline is of particular importance, as it will greatly increase the possibility of transit of Caspian oil. Poland is also interested in the pipeline to run from the Yamal fields to the western and southern parts of Europe.

As a country with a specific strategic position on the eastern border of the EU and having accumulated vast experience in the realities of this situation, Poland can play the role of a coordinator of territorial development programme planning on the European continent. Related issues of environmental protection and environmental disasters also contribute to finding opportunities for EU's cooperation with the relevant countries in the region.

EU enlargement to the East has had extremely important consequences for the relations of the EU - and in particular those of the new Member States - with its neighbours on the eastern side of the Union abroad, especially in the context of the Schengen rules, including border control and the need for visas. Cooperation in combating organised crime, illegal migration and drug trafficking gains an exceptional value, despite the fact that in the former USSR these phenomena are especially common, and it is through this space that transit routes of illegal immigrants and drugs stretch.

Openness to EU contacts with citizens of countries outside its eastern borders has a decisive influence on the processes of transformation in these countries and their adaptation to the neighbourhood of the EU. This is a profound political problem with farreaching social consequences. Poland joined the Schengen Area with the simultaneous introduction of visas for citizens of the Eastern Partnership countries (in order to effectively protect the country's borders), which will prevent our eastern neighbours from establishing better contacts with the system of the European standards of freedom, democracy and market economy. Poland tries to simplify the procedure for granting entry visas to expand its network of consulates and implement a multi-visa system and low payment for their provision.

In the policy towards the Eastern Partnership countries a very important issue arises as to the impact on the education system of these countries, their culture and the media in order to develop a new mentality and democratic thinking, disseminating human rights and helping to build civil societies.

Considering all of the above, it is necessary to take measures to overcome barriers to free movement of people and ideas both within individual Eastern Partnership countries and between them. The role of these efforts transforms into contacts between organisations and institutions existing in these countries with their counterparts in the European Union. In particular, the activities of non-governmental organisations and the 
expansion of the European information space of the Eastern Partnership countries are worth mentioning in this context.

Poland plays an important role in cross-border and interregional cooperation as an effective tool for building good-neighbourly relations in the interests of social, cultural and scientific relations based on economic cooperation. Expanding contacts at the lowest level promotes growth of mutual trust. In addition to the spread of European standards of democracy and ideas of civil society, they also promote a system of shared values.

Introducing the policy of expanding cross-border and inter-regional cooperation with the Eastern European partners and countries further to the east of the continent, Poland has signed several international agreements, including those with Belarus (1992), Ukraine (1993), Georgia (1993) and Moldova (1998).

Intergovernmental commissions and advisory structures were created to coordinate the necessary activities, such as: Polish -Ukrainian intergovernmental commission for interregional cooperation (1996), Polish-Belarusian intergovernmental coordination commission for cross-border cooperation (1996).

Created along the borders, Euroregions entail institutionalised cross-border cooperation involving regional and local authorities. Before that, there were four Euroregions that were settled along the eastern and partly - the southern border, namely the Polish-Ukrainian-Hungarian-Romanian-Slovak Carpathian Euro-region (1993), the Polish-Belarusian-Ukrainian Euroregion Bug (1995), the Polish-Belarusian Euroregion Niemann-Litovsk (1997), and the Kaliningrad District; Baltic Euroregion was invited to cooperate in the framework of that Euroregion (1998).

Polish government administration, including regional and local authorities are committed to treat the development of cross-border relations, with compensation as a necessary factor distinguishing future boundaries, which brings the interpenetration of cultures and initiates economic development in the regions involved in this cooperation. These authorities believe that in terms of EU enlargement to the East, cross-border and regional cooperation should play a crucial role in overcoming the image of the new partition of Europe, and is now ready to take on an appropriate policy against such division.

To improve the efficiency of the existing diversity of future cooperation along the eastern and south-eastern border of the European Union, with the north-western outskirts of the surrounding regions of the Baltic States, the District of Kaliningrad and the PolishBelarusian-Ukrainian border should establish the widest possible exchange of experience and expertise estimates. These measures are widely supported in the framework of cooperation between the Baltic, Central European Initiative, or other structures created at the suggestion of Poland.

Poland hopes that the EU financial mechanisms designed to support such cooperation, such as INTERREG, PHARE, CBC, TACIS, will be optimised, which will allow their more efficient use in those countries and help stabilising their economic development, environmental protection and human contacts.

Poland has established good relations with its neighbours to the East. After joining the European Union it ceased having international legal or border problems as well as those associated with ethnic minorities. Close collaboration was established with other candidates for accession to the EU - the Baltic States and the Visegrad Group. 
During the period of transformation of its economic and political system, democracy, rule of law and market economy, and adaptation of its economic, political and legal system to the standards of the European Union, Poland has acquired vast experience. This experience is shared with the eastern states of the future borders of the European Union in order to help them adjust to the new conditions of the EU neighbourhood. Poland is ready to extend its cooperation and develop good-neighbourly relations with the surrounding enlarged EU countries and regions, especially with Belarus and Ukraine. Given the positive experience gained during the formation of contacts in the Permanent Polish-Ukrainian conference on EU enlargement, which in turn is part of the EU's Common Strategy on Ukraine, Poland is ready to support this form of cooperation. In the process of sharing their experience gained during the preparation of Ukraine for the EU membership, Poland closely followed to the latter and no claim was put forward in the context of its future institutional links with the EU. By positively treating the invitation to join the European Union, which applies to the states taking part in the accession negotiations, Poland at the same time is ready to participate in the implementation of projects under the Action Plan designed for Russia and Ukraine.

Despite the isolation of Belarus by reason of the current policies implemented by its leader, the European Union cannot keep this country outside its attention, which will soon become its neighbour. It should pay particular attention to the case of initiation of participation of Belarus in the EU information programmes and maintaining the information flow from the EU to Belarus.

Polish intellectual and administrative resources can be used to support the implementation of the EU programmes aimed at training the administrative staff of the Eastern Partnership countries, which will subsequently be involved in collaboration with the advanced European Union (especially the part that is responsible for establishing relationships within the immediate neighbourhood).

In summarising the above, according to Poland, all the EU initiatives aimed at the Eastern Partnership countries, which aim to promote the development of the eastern policy of the Union, should be agreed with the candidate countries for accession. Poland is interested in participating in such consultations.

Scientists and experts in independent research centres are now engaged in a comprehensive study of the existing problems of the new EU border in Ukraine. A major achievement on the analysis of the current state borders of Ukraine and the EU is a project of the Centre for Peace, Conversion and Foreign Policy (Kyiv), called "Frontiers of Ukraine". Moreover, members of the same Centre have a vital job today, namely, to provide a translation of the Schengen Agreement into Ukrainian. Important and urgent scientific achievements are contained in a comprehensive study of borders "Enlargement of the European Union: impact on Ukraine's relations with its Central European Neighbours", which is sponsored by the Institute for Regional and Euro-Integration Studies "EuroRegio Ukraine".

However, it is important to emphasise that at present a comprehensive academic level research on EU borders and boundaries with Ukraine is still lacking. The relevance and importance of this issue is determined by modern developments, namely the implementation of Ukraine's foreign policy in the new system of international relations 
on the Eurasian continent. Indeed, in view of the latest expansion of the European Union during 2004-2007, Ukraine has direct borders with the EU, which has not only radically changed the system of relations, but also defined a number of new problems for the old and the new western and eastern borders of Ukraine. In fact, the example of transformation of the external border to the inner border of the EU can not only see the "future", but objectively identify practical solutions to modern challenges of the new EU-Ukraine border.

Today in Ukraine only a narrow understanding of border transformation prevents understanding the border as a holistic, dynamic process which is inherent in the internal logic of development. The essence of the problem is determined not only in the presence of an entirely different approach to explaining the process of transforming the border into broader geopolitical, civilisational dimensions, as well as the methods and ways of using their own ideas of scientific knowledge or scientific approach to reality. That is, if a system or fragmented use of any concept is based on a comprehensive analysis of complex phenomena, or trying to squeeze the phenomena and events that are defined as an a priori scheme or situationally and adapt them to certain ideologies that have nothing to do with reality. This also partly explains how the current problem of borders or border issues or even cross-border cooperation has not only been interpreted in a simplified manner, but also does not receive enough attention.

Formation of a new eastern border of the EU-Central and Eastern Europe and Ukraine identifies a number of critical implications for Ukraine, particularly, the change of border crossing points in the Central European region in general. The first and the main result for Ukraine on the formation of the new Eastern border of the EU is part of more than ten years of the liberal regime of border crossing between Ukraine and CE and the formation of a territorial stability in the Central European region.

An extremely important consequence of the formation of the new Eastern border of the EU is security. The issues of border management and security are more focused on issues of migration, precisely control of the situation regarding illegal immigration that never disappears and only changes its shape and size. In addition, all the other problems are of technical and financial nature. The existing asymmetry of socio-economic development and the "depressed" border regions of Ukraine and Poland-SlovakiaHungary will further increase the already strong conditions of economic development at the bordering regions of Poland, Slovakia and Hungary as full members of the EU.

\section{Conclusions}

Signing a free trade area agreement between the European Union and the Eastern Partnership members will bring clear benefits for both parties to the agreement. Creating a free trade area will bring much more economic benefit than signing a customs union agreement with Russia. There are several reasons why integration with the EU is more profitable, compared to that with Russia. The fact that the agreement between EaP countries and the EU is not an ordinary free trade agreement, but is a DCFTA, brings even more benefits. Goods produced in EaP country markets will have better quality 
and be cheaper. Harmonisation of some legal aspects will allow opening borders with the European Union. This will also increase exchange of experience between the EU and its partners. Nevertheless, creating a FTA can bring political dangers from Russia, which will entail the respective economic consequences.

\section{References}

1. Albrycht, I. Partnerstwo Wschodnie w kontekscie Europejskiej Polityki Sasiedzkiej I Agendy Grupy Wyszehradzkiej. Warszawa, 2009.

2. Balassa, B. The Theory of Economic Integration, 1961.

3. Borkowski, J. Polityka Sąsiedztwa Unii Europejskiej, Torun, 2010.

4. Eastern Partnership, Strategia na rok 2011 i lata następne https://www.google.pl/url ? sa $=\mathrm{t} \& \mathrm{rct}=\mathrm{j} \& \mathrm{q}=\& \mathrm{esrc}=\mathrm{s} \&$ source $=$ web \&cd $=3 \& \mathrm{ved}=0 \mathrm{CDUQFjAC} \& u r l=h t \mathrm{tp} \% 3 \mathrm{~A} \%$ 2F\%2Fwww.pism.pl\%2Ffiles\%2F\%3Fid_plik\%3D3101\&ei=f76MT7PNC8PktQbjrb DYCQ\&usg=AFQjCNGGIeNda81QsR_z7Qr-SXEBDIcPRQ\&sig2=IgTcfFL9V3dO ITx8Mle4rA.

5. Internet portal of Partnerstwo Wschodnie http://www.easternpartnership.org/

6. Kundera, J. Poland In European Single Market, Wroclaw, 2010.

7. Lipsey, R. The theory of customs unions: a general survey // Economic Journal, Vol. 70, 1960 p. 496-513.

8. Mucha-Leszko, B. Polityka Handlowa Unii Europejskiej wobec krajów trzecich, Warszawa, 2010.

9. Tinbergen, J. Customs unions: influence of their size on their effect // Zeitschrift der gesamten Staatswissenschaft, 1957, Vol. 113, p. 404-414.

10. Vademecum on financing in the frame of the eastern partnership http://eeas.europa.eu/eastern/docs/eap_vademecum_en.pdf str. 3-4.

11. Viner, J. The Customs Union Issue, New York: Carnegie Endowment for International Peace, 1950.

12. Internet portal of Radio Swoboda http://www.radiosvoboda.org/content/article/ 24177770.html.

13. Internet portal of the Ministry of Foreign Affairs of Ukraine http://www.kmu.gov. ua/control/publish/article?art_id=224168250.

\section{TARPTAUTINĖS PREKYBOS TARP ES IR RYTŲ PARTNERYSTĖS BLOKO ŠALIŲ PLĖTRA. UKRAINOS IR LENKIJOS PAVYZDYS}

Santrauka. Rytų dimensija Europos Sąungos teritorijoje yra viena iš svarbiausių Europos kaimynystės politikos aspektų. Rytų partnerystė yra programa, kurios tikslas yra pagerinti ES ir šalių partnerių bendradarbiavimą. Rytų partnerystès programos rezultatas turètų būti sutarties pasirašymas su kiekvienu partneriu. Tokios sutarties pasirašymas gali turèti tiek privalumų, tiek trūkumų ir sukelti pavojų abiem pusems. Straipsnyje nagrinejjamas geriausias ekonominės integracijos su Rytu partnerystes šalimis variantas - Rusijos, Baltarusijos ir Kazachstano muitų sąunga arba laisvosios prekybos zona su Europos Sąjunga. Ukraina ir Lenkija turi glaudžius istorinius, kultūrinius ir eko- 
nominius ryšius. Jų pavyzdys geriausiai tinka nagrinèti ekonominio ir tarpvalstybinio bendradarbiavimo tarp ES ir Rytų partnerystès šalių rezultatus.

Daniel BUTYTER - University of Wroclaw, Poland.

Daniel BUTYTER - Vroclavo universitetas, Lenkija. 